\title{
High-dependency units play a key role in the treatment of a Chinese military patient who developed liver failure while abroad
}

\author{
Chen Li, Hai-Bin Su, Xiao-Yan Liu, Li-Na Zhang and Jin-Hua Hu*
}

\begin{abstract}
High-dependency units (HDUs) provide high-level care to patients who suffer from single organ failure, with the exception of respiratory failure requiring mechanical ventilation; HDUs serve as an intermediary between general wards and Intensive Care Units. Due to military and civilian needs, our hospital has established a unique HDU for patients with liver disease in China. A Chinese military officer in the United Nations Peacekeeping Forces in South Sudan was transferred to our HDU for liver failure treatment in 2018. The patient's disease status, nutrition, sleep habits, and psychological behaviour were monitored on different scales. The patient was provided with vascular monitoring, telemetry, pulse oximetry, drug treatment, nutritional support, sleep intervention, psychological intervention, and humanistic care by a multidisciplinary treatment team. After treatment, the patient recovered and avoided liver transplantation. Based on the experience with this HDU, this new model may create an efficient treatment process for military and civilian patients with severe liver disease at home or abroad.
\end{abstract}

Keywords: High-dependency units, Liver failure, Treatment, Military patient

High-dependency units (HDUs), also known as intermediate care units and step-down units, were established to provide a level of care between the general ward and the Intensive Care Unit (ICU) [1-3]. In the United Kingdom, this level of care is thought to be suitable for patients suffering from single organ failure, with the exception of those with respiratory failure requiring mechanical ventilation [1-3]. However, the indications for HDU admission vary regionally and even within institutions [1-4]. HDUs are believed to confer advantages in the management of postoperative, paediatric, cardiac, and respiratory syndromes, and HDU admission may reduce the need for unnecessary ICU admission [4-6]. As such, it has been argued that HDUs may be cost-saving and improve access to the ICU for patients who are truly dependent on critical care resources [6]. Furthermore, HDUs may facilitate earlier ICU discharge and reduce the likelihood of ICU readmission [7]. One study even suggested that HDUs may improve patient satisfaction [8]. Last, increased humanistic care in HDUs may help

\footnotetext{
* Correspondence: m13910020608@163.com

Liver Failure Treatment and Research Center, The Fifth Medical Center of Chinese PLA General Hospital, Beijing 100039, China
}

reduce the incidence of post-intensive care syndrome in patients who are otherwise at risk [9]. However, the role of HDUs in the management of patients with severe liver disease (SLD) has received limited attention [10]. The purpose of this letter is to describe the first HDU for SLD in China and showcase its performance using an example case.

\section{Description of our liver disease HDU}

In China, liver disease affects approximately 300 million people, which accounts for a significant proportion of the global burden $[11,12]$. Patients with SLD, such as acute liver failure, acute-on-chronic liver failure and acute decompensation in the setting of cirrhosis, are frequently admitted to intensive care. In China, these patients often present with coagulopathy, renal insufficiency, and altered mental status, but not respiratory failure [13]. Many SLD patients could therefore be managed in HDUs with close monitoring.

In recent years, the Chinese military has observed a high incidence of liver disease among military service personnel overseas [14-16]. Frequently, medical resources overseas cannot meet the treatment needs of

(c) The Author(s). 2019 Open Access This article is distributed under the terms of the Creative Commons Attribution 4.0 International License (http://creativecommons.org/licenses/by/4.0/), which permits unrestricted use, distribution, and reproduction in any medium, provided you give appropriate credit to the original author(s) and the source, provide a link to the Creative Commons license, and indicate if changes were made. The Creative Commons Public Domain Dedication waiver (http://creativecommons.org/publicdomain/zero/1.0/) applies to the data made available in this article, unless otherwise stated. 
these patients. For these reasons, a specialized HDU for patients with SLD was established in our hospital. The 7 bed unit was opened in 2017. For context, our hospital has 1200 beds and approximately 50,000 inpatient visits per year.

Admission to this specialized HDU requires the presence of SLD with serious complications, including ascites, acute kidney injury, hepatic encephalopathy ( $\leq$ grade 2), gastrointestinal bleeding, infection, and sepsis. Patients with respiratory failure and high-grade hepatic encephalopathy ( $\geq$ grade 3 ) are admitted to the ICU. Patients can be admitted from any of the following locations: emergency department, the general ward when deteriorating, and the ICU after stabilization. An additional function of the HDU is to stabilize, monitor, and manage patients prior to liver transplantation. In normal times, the HDU is used to treat domestic military and civilian patients with SLD. However, priority is given to military personnel with SLD who have been overseas.

The HDU nurse-to-patient ratio is 1:2-1:3. Clinical staff, including physicians and nurses, are present $24 \mathrm{~h} /$ d, $7 \mathrm{~d} /$ week. The staff is composed of a multidisciplinary treatment team consisting of doctors, nurses, clinical pharmacists, dieticians, physiotherapists, and psychologists. All team members evaluate the condition of the patient and work together to develop an individualized treatment plan for the patient. The chief physician of the HDU is the team leader and is responsible for coordinating weekly meetings to discuss each patient's condition and management plan. Specific services and monitoring available to patients in the unit include arterial catheterization for invasive monitoring of blood pressure, central venous catheterization, telemetry, and continuous pulse oximetry. Admitted patients also receive an assessment of their nutritional status with recommendations for optimization, a psychological evaluation and management as necessary, and interventions to optimize sleep. In addition, the HDU can provide bedside artificial liver support (ALS) and renal replacement therapy. Moreover, the unit has a telemedicine terminal that is used to coordinate medical evacuations and provide management expertise for military service members with SLD prior to HDU admission.

\section{Case report of an overseas military patient treatment}

Our specialized HDU has established a bridge between the general ward and the ICU (Fig. 1). It was recently tested in the treatment of an overseas military patient with liver failure. This Chinese officer in the United $\mathrm{Na}$ tions Peacekeeping Forces of South Sudan was transferred to our HDU with liver failure in February 2018. This 41-year-old man, with a past history notable for hypertension and diabetes, had no prior history of liver disease. In South Sudan, he developed fever, fatigue, anorexia, and jaundice. On laboratory evaluation, he was noted to be coagulopathic with the following additional abnormalities: alanine aminotransferase $(5410 \mathrm{U} / \mathrm{L}$; normal < $40 \mathrm{U} / \mathrm{L})$, aspartate aminotransferase $(3475 \mathrm{U} / \mathrm{L}$; normal $<40 \mathrm{U} / \mathrm{L})$, total bilirubin $(225.1 \mu \mathrm{mol} / \mathrm{L}$; normal

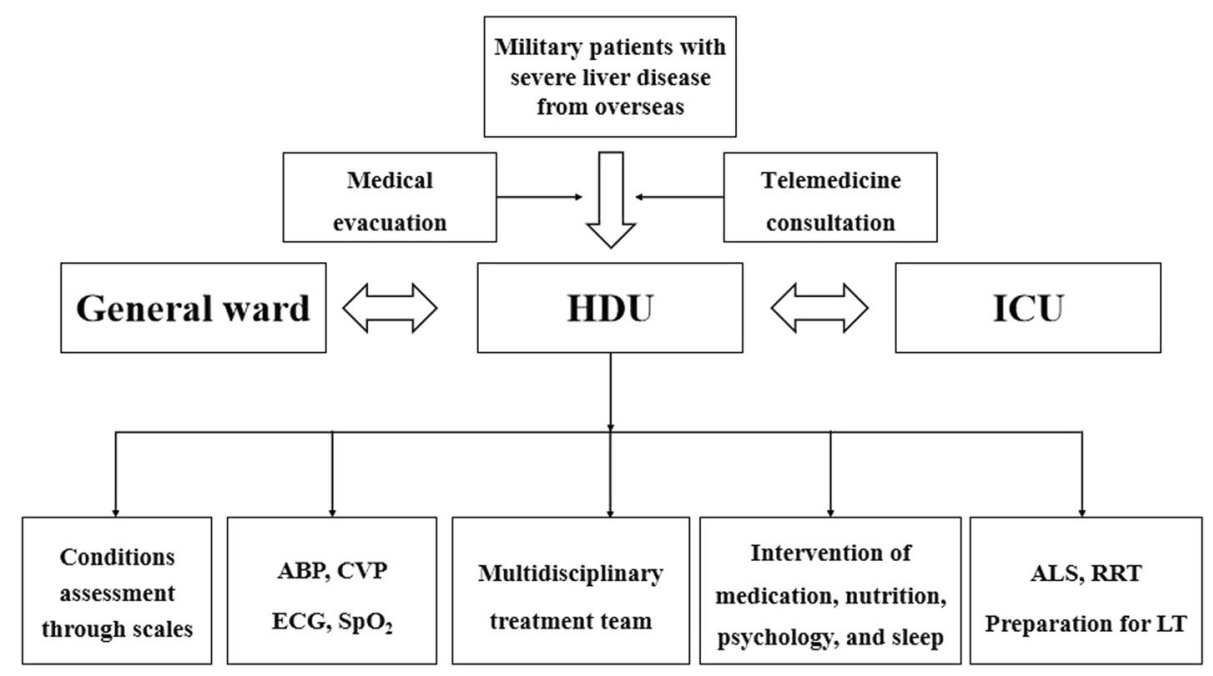

Fig. 1 Treatment process for military patients with severe liver disease (SLD) from overseas. When military patients experience SLD overseas, they can be transferred to our high-dependency units (HDUs) for treatment by telemedicine consultation and medical evacuation. In this HDU, patients can receive therapy from a multidisciplinary treatment team. Arterial blood pressure (ABP) monitoring, central venous pressure (CVP) monitoring, electrocardiogram (ECG), and pulse oxygen saturation $\left(\mathrm{SpO}_{2}\right)$ monitoring are provided for the patients. Artificial liver support (ALS), renal replacement therapy (RRT), preparation for liver transplantation (LT), nutritional support treatment, psychological assessment, and sleep interventions are provided to the patients. According to their condition, patients are selected for transfer to the general ward or the intensive care unit (ICU) 
$3.4-20.5 \mu \mathrm{mol} / \mathrm{L})$, prothrombin activity $(21.5 \%$; $65-$ $130 \%)$ and international normalized ratio (2.12; normal 0.8-1.2). Following the HDU-based telemedicine consultation, a preliminary diagnosis of acute viral hepatitis was suggested, and the patient was evacuated by air to our HDU.

Upon admission, vascular monitoring (arterial and central venous line), telemetry, and pulse oximetry were initiated. He was prepared for ALS and liver transplantation. Additional testing confirmed a diagnosis of hepatitis A virus-related liver failure with nutritional risk, sleep disorders, and psychological disorders. In the setting of our multidisciplinary care plan, the patient recovered and avoided liver transplantation. This case exemplifies what has become an efficient HDU-based strategy in the management of patients with SLD. The characterization of his overall condition upon admission to the HDU, specific assessments and interventions, and measures at HDU discharge on day 31 are characterized in Table 1.

Table 1 Interventions, scale scores at HDU admission and discharge of the patient

\begin{tabular}{|c|c|c|c|}
\hline Variable & $\begin{array}{l}\text { Admission } \\
\text { score }\end{array}$ & Intervention & $\begin{array}{l}\text { Discharge } \\
\text { score }\end{array}$ \\
\hline SOFA & 4 & \multirow{2}{*}{$\begin{array}{l}\text { Magnesium isoglycyrrhizinate, } \\
\text { ursodeoxycholic acid, } \\
\text { adenosylmethionine } \\
\text { butanesulfonat, clotting factor }\end{array}$} & 2 \\
\hline MELD & 23.4 & & 5.4 \\
\hline NRS 2002 & 4 & $\begin{array}{l}\text { Carbohydrate, amino acid, fat, } \\
\text { vitamins, dietary fibre }\end{array}$ & 1 \\
\hline PSQI & 21 & Sedative, physiotherapy & 10 \\
\hline SCL90-R & 188 & \multirow{13}{*}{$\begin{array}{l}\text { Psychological counselling, } \\
\text { humanistic care }\end{array}$} & 108 \\
\hline GSI & 2.1 & & 1.2 \\
\hline PST & 40 & & 14 \\
\hline PSDI & 3.5 & & 2.3 \\
\hline SOM & 2.2 & & 1.2 \\
\hline $\mathrm{O}-\mathrm{C}$ & 2.2 & & 1.0 \\
\hline IS & 1.2 & & 1.1 \\
\hline DEP & 2.5 & & 1.2 \\
\hline ANX & 2.0 & & 1.1 \\
\hline $\mathrm{HOS}$ & 2.2 & & 1.0 \\
\hline PHOB & 1.7 & & 1.1 \\
\hline PAR & 1.5 & & 1.0 \\
\hline PSY & 1.8 & & 1.2 \\
\hline
\end{tabular}

ANX. Anxiety; DEP Depression, GSI General symptomatic index, HDU Highdependency unit, HOS Anger-hostility, I-S Interpersonal sensitivity, MELD Model for end-stage liver disease, NRS Nutrition risk screening; O-C Obsessivecompulsive, PAR Paranoid ideation, PHOB Phobic anxiety, PSDI Positive symptom distress index, PSQI Pittsburgh sleep quality index, PST Positive symptom total, PSY Psychoticism, SCL90-R Symptom check list 90-revised, SOFA Sequential organ failure assessment, SOM Somatization

\section{Conclusions}

This specialized HDU allows a proportional use of medical resources and likely prevents ICU admissions for patients like the one we have described. Our specialty unit and multidisciplinary treatment team optimize the diagnosis, management, evaluation, and triage of patients with SLD. The efficiency of this model is very likely to save the lives of military and civilian patients with SLD, a condition that may progress rapidly to death without appropriate expertise and resources. Consideration should be given to replicating our model at other military or civilian medical centres, including mobile centres, military medical ships and aircrafts.

\section{Abbreviations}

ALS: Artificial liver support; ANX: Anxiety; DEP: Depression; GSI: General symptomatic index; HDU: High-dependency unit; HOS: Anger-hostility; ICU: Intensive care unit; I-S: Interpersonal sensitivity; MELD: Model for endstage liver disease; NRS: Nutrition risk screening; O-C: Obsessive-compulsive; PAR: Paranoid ideation; PHOB: Phobic anxiety; PSDI: Positive symptom distress index; PSQI: Pittsburgh sleep quality index; PST: Positive symptom total; PSY: Psychoticism; SCL90-R: Symptom check list 90-revised; SLD: Severe liver disease; SOFA: Sequential organ failure assessment; SOM: Somatization

\section{Acknowledgements}

Not applicable.

\section{Authors' contributions}

$C L, H B S, X Y L, L N Z$ and $J H H$ participated in the treatment of this patient and were involved in the development of the conclusions. $C L$ wrote the first draft with assistance from HBS, JHH and XYL. HBS and JHH edited the final draft. All authors have read and approved the final manuscript.

\section{Funding}

Not applicable.

Availability of data and materials

Not applicable.

Ethics approval and consent to participate

Not applicable.

Consent for publication

Not applicable.

Competing interests

All authors declare that they have no competing interests.

Received: 29 May 2019 Accepted: 6 September 2019

Published online: 16 September 2019

\section{References}

1. De Silva RJ, Anderson A, Tempest H, Ridley S. Sequential organ scoring as a measure of effectiveness of care in the high-dependency unit. Anaesthesia. 2001:56(9):850-4.

2. Plate JDJ, Hietbrink F, Leenen LPH, Peelen LM. Predicting early deterioration of admitted patients at the intermediate care unit. J Crit Care. 2018;48: 97-103.

3. Prin $\mathrm{M}$, Wunsch $\mathrm{H}$. The role of stepdown beds in hospital care. Am J Respir Crit Care Med. 2014;190(11):1210-6.

4. Simpson CE, Sahetya SK, Bradsher RW 3rd, Scholten EL, Bain W, Siddique $\mathrm{SM}$, et al. Outcomes of emergency medical patients admitted to an intermediate care unit with detailed admission guidelines. Am J Crit Care. 2017;26(1):e1-10.

5. Hukins C, Wong M, Murphy M, Upham J. Management of hypoxaemic respiratory failure in a respiratory high-dependency unit. Intern Med J. 2017; 47(7):784-92. 
6. Plate JDJ, Peelen LM, Leenen LPH, Hietbrink F. Optimizing critical care of the trauma patient at the intermediate care unit: a cost-efficient approach Trauma Surg Acute Care Open. 2018;3(1):e000228.

7. Prin $\mathrm{M}$, Harrison D, Rowan $\mathrm{K}$, Wunsch $\mathrm{H}$. Epidemiology of admissions to 11 stand-alone high-dependency care units in the UK. Intensive Care Med. 2015;41(11):1903-10.

8. Armstrong K, Young J, Hayburn A, Irish B, Nikoletti S. Evaluating the impact of a new high dependency unit. Int J Nurs Pract. 2003;9(5):285-93.

9. Rawal G, Yadav S, Kumar R. Post-intensive care syndrome: an overview. J Transl Int Med. 2017;5(2):90-2.

10. Dupont B, Delvincourt M, Koné M, du Cheyron D, Ollivier-Hourmand I Piquet MA, et al. Retrospective evaluation of prognostic score performances in cirrhotic patients admitted to an intermediate care unit. Dig Liver Dis. 2015;47(8):675-81.

11. Kyu HH, Abate D, Abate KH, Abay SM, Abbafati C, Abbasi N, et al. Global, regional, and national disability-adjusted life-years (DALYs) for 359 diseases and injuries and healthy life expectancy (HALE) for 195 countries and territories, 1990-2017: a systematic analysis for the Global Burden of Disease Study 2017. Lance. 2018;392(10159):1859-1922.

12. Wang FS, Fan JG, Zhang Z, Gao B, Wang HY. The global burden of liver disease: the major impact of China. Hepatology. 2014;60(6):2099-108.

13. Wu T, Li J, Shao L, Xin J, Jiang L, Zhou Q, et al. Development of diagnostic criteria and a prognostic score for hepatitis B virus-related acute-on-chronic liver failure. Gut. 2018;67(12):2181-91.

14. Jacobsen $\mathrm{KH}$, Wiersma ST. Hepatitis a virus seroprevalence by age and world region, 1990 and 2005. Vaccine. 2010;28(41):6653-7.

15. Yooda AP, Sawadogo S, Soubeiga ST, Obiri-Yeboah D, Nebie K, Ouattara AK, et al. Residual risk of HIV, HCV, and HBV transmission by blood transfusion between 2015 and 2017 at the regional blood transfusion Center of Ouagadougou, Burkina Faso. J Blood Med. 2019;10:53-8.

16. Wu X, Chen P, Lin H, Hao X, Liang Z. Hepatitis E virus: current epidemiology and vaccine. Hum Vaccin Immunother. 2016;12(10):2603-10.

Ready to submit your research? Choose BMC and benefit from:

- fast, convenient online submission

- thorough peer review by experienced researchers in your field

- rapid publication on acceptance

- support for research data, including large and complex data types

- gold Open Access which fosters wider collaboration and increased citations

- maximum visibility for your research: over $100 \mathrm{M}$ website views per year

At $\mathrm{BMC}$, research is always in progress.

Learn more biomedcentral.com/submissions 